\title{
Banana Growing in the Florida Home Landscape ${ }^{1}$
}

\author{
Jonathan H. Crane, Carlos F. Balerdi, and lan Maguire ${ }^{2}$
}

Scientific name: Musa acuminata and Musa balbisiana

Common names for banana: English - banana, plantain; Spanish - banano, platano, guineo, cambur

Common names for plantain : English plantain, horse banana; Spanish - platano

Family: Musaceae

\section{Relatives of banana within the Order} Zingiberales : Numerous ornamental plants including traveler's palm, bird-of-paradise, heliconia, and ginger.

\section{Introduction}

Bananas are vigorously growing, monocotyledonous herbaceous plants. There are two species of banana, Musa acuminata and M. balbisiana, and most banana cultivars are hybrids of these species. Banana cultivars vary greatly in plant and fruit size, plant morphology, fruit quality, and disease and insect resistance. Most bananas have a sweet flavor when ripe; exceptions to this are cooking bananas and plantains.
Plantains are hybrid bananas in which the male flowering axis is either degenerated, lacking, or possesses only relicts of male flowers. Plantains are always cooked before consumption and are higher in starch than bananas. The two groups of plantains, French and Horn, produce fewer fruit per plant than sweet bananas. The groups differ in whether the male parts of the inflorescence are persistent or absent.

\section{History and Distribution}

The banana and plantain are native to southeast Asia, where they have been cultivated for thousands of years. Bananas are believed to have been introduced to Africa in prehistoric times. Recent evidence suggests bananas were introduced into the New World (Ecuador) by southeast Asians around 200 B.C., and more recently by Portuguese and Spanish explorers in the early 16th century. The Portuguese introduced bananas into the Canary Islands and the Spanish to the Island of Hispaniola during the 1500 s.

Susceptibility to frost keeps the banana from spreading beyond the tropics and the warm subtropics. However, bananas are grown commercially in a number of subtropical areas such

1. This document is HS-10, one of a series of the Department of Horticultural Sciences, Florida Cooperative Extension Service, Institute of Food and Agricultural Sciences, University of Florida. First printed 1972 as FC-10. Major revision January 1998 and September 2005. Please visit the EDIS Website at http://edis.ifas.ufl.edu or http://fruitscapes.ifas.ufl.edu

2. Jonathan H. Crane, Professor and Tropical Fruit Crops Specialist, Tropical Research and Education Center, Homestead, Florida, and Carlos F. Balerdi, Professor and Multi-County Tropical Fruit Crops Extension Agent, Miami-Dade County Cooperative Extension Service; I. Maguire, Media Artist, Tropical Research and Education Center, Homestead, Florida; Institute of Food and Agricultural Sciences, University of Florida, Gainesville, 32611.

The Institute of Food and Agricultural Sciences (IFAS) is an Equal Opportunity Institution authorized to provide research, educational information and other services only to individuals and institutions that function with non-discrimination with respect to race, creed, color, religion, age, disability, sex, sexual orientation, marital status, national origin, political opinions or affiliations. U.S. Department of Agriculture, Cooperative Extension Service, University of Florida, IFAS, Florida A. \& M. University Cooperative Extension Program, and Boards of County Commissioners Cooperating. Larry Arrington, Dean 
as Australia, Morocco, South Africa, Egypt, Israel, the Canary Islands, and south Florida. In some areas, bananas are grown inside plastic or glass covered structures.

Plantains are an important food source in parts of Africa, southern India, and throughout tropical America. This is because of the ease and stability of production and the highly nutritious nature of the fruit.

Bananas have been grown in scattered locations throughout Florida since their introduction during the 16th century. Limited commercial production has occurred since the late 1800s. Florida is considered a climatically marginal area for commercial banana production due to our subtropical climate and occasional freezes. However, small scale commercial production does occur in southern Florida and producers supply local and regional markets.

\section{Uses}

Bananas are eaten fresh and used in salads, desserts, breads, and candy. Bananas are a good source of ascorbic acid (Vit. C), Vitamin $\mathrm{B}_{6}$, and potassium. Plantains are cooked before use and may be baked, fried, or grilled. Plantains have nutritive value similar to that of fresh eating bananas with additional Vitamin A. They are an excellent source of carbohydrate (starch).

Banana plants may also be used in the home landscape for ornamental purposes. The range in plant sizes and color and fruit shapes adds a tropical atmosphere to the yard. In addition, trees may be used as sun-screens to shade southeastern or western walls.

\section{Plant Description}

Whole plant : The banana is a fast-growing plant consisting of one or more pseudostems (upright, trunk-like structures) formed by tightly packed concentric layers of leaf sheaths, an underground rhizome, and a fibrous root system. The entire plant is called a mat. The pseudostem constitutes the functional trunk, which supports the leaves and the flower and fruit bearing stalk.

\section{Types of suckers:}

- Sword suckers - small pseudostems (12-48 inches tall) with narrow leaves. Sword suckers will develop into fruitful psuedostems at maturity

- Water suckers - small pseudostems (12-48 inches tall) with broad leaves. Water suckers are not well attached to the rhizome and generally produce weak plants and less fruit than sword suckers.

- Peepers - very small pseudostems (1-12 inches tall) that develop into either sword or water suckers.

Rhizome (corm): A rhizome is an underground stem with numerous meristems (growing points) from which the pseudostems, flowering and fruiting stalks, and fibrous roots arise.

Sheath and leaves : The banana leaf consists of a long, tube-like structure called a sheath, a stout petiole (leaf stalk), and a lamina or leaf blade. The tight packing of numerous sheaths form the pseudostem. One pseudostem may have over 40 leaves during its lifetime.

Roots : Numerous (200-500) fibrous roots arise from the rhizome. In well drained, deep, fertile soils, roots may extend $5 \mathrm{ft}(1.5 \mathrm{~m})$ deep and $16 \mathrm{ft}(4.9 \mathrm{~m})$ laterally.

Flowers and fruit : The banana inflorescence (flowering stalk) emerges from the center of the pseudostem 10 to 15 months after planting; by this time 26 to 32 leaves have been produced. The process of banana flowering is called shooting. The flowers appear spirally along the axis of the inflorescence in groups of 10 to 20 , covered by purplish-to-greenish fleshy bracts that shed as flowering development progresses. The first flowers to emerge are functionally female. In the edible cultivars, the rapidly growing ovaries develop parthenocarpically (without pollination) into clusters of fruits, called "hands." The fruit is a berry. Although most banana cultivars produce seedless fruit, some are fertile and can set seed. The last flowers to emerge are functionally male. In plantains, the male flowers may be absent or greatly reduced. 
The time from shooting to fruit harvest depends upon temperature, cultivar, soil moisture, and cultural practices, and ranges from 80 to 180 days. The time from planting a small banana sucker and harvest ranges from 9 to 20 months depending upon temperatures, cultivar, and cultural practices.

\section{Environmental Factors}

Temperature: Bananas flourish under uniformly warm to hot conditions. Shoot growth is best between $78^{\circ} \mathrm{F}$ to $82^{\circ} \mathrm{F}\left(26-28^{\circ} \mathrm{C}\right)$ and fruit growth at $84^{\circ} \mathrm{F}$ to $86^{\circ} \mathrm{F}\left(29-30^{\circ} \mathrm{C}\right)$. Plant growth slows below $60^{\circ} \mathrm{F}\left(16^{\circ} \mathrm{C}\right)$ and stops at $50^{\circ} \mathrm{F}$ $\left(10^{\circ} \mathrm{C}\right)$. Symptoms of chilling injury (temperatures below $60^{\circ} \mathrm{F} / 16^{\circ} \mathrm{C}$ but above $32^{\circ} \mathrm{F} / 0^{\circ} \mathrm{C}$ ) include failure of the flowering stalk or fruit bunch to emerge from the pseudostem (called choking), development of a dull yellow or greenish-gray color to ripening fruit, distorted fruit shape, and an increase in fruit rotting.

Chilling damage and irreversible freeze damage may occur at or below $3^{\circ} \mathrm{F}\left(0^{\circ} \mathrm{C}\right)$. Symptoms of freeze damage include a water-soaked appearance to all above ground parts of the banana plant and desiccation, browning, and death of leaves, pseudostems, and fruit. Temperatures below $28^{\circ} \mathrm{F}$ $\left(-2^{\circ} \mathrm{C}\right)$ may kill plants to the ground. However, new growth usually sprouts from the underground rhizome with the return of warm weather.

Temperatures at or above $98^{\circ} \mathrm{F}\left(37^{\circ} \mathrm{C}\right)$ may result in leaf scorch and emerging new leaves may have very narrow blades.

Wind: Wind is a common constraint in subtropical production areas. In addition, continuously windy weather may cause severe leaf shredding (mild shredding may be beneficial), drying of the leaves, and plant crown distortion. Winds above $25 \mathrm{mph}$ and $45 \mathrm{mph}$ may cause tall and short banana cultivars (respectively) to topple.

Drought and flooding: Temperature and soil moisture are the most important factors in banana production. Lack of water at any time may cause a reduction in fruit number and size and ultimate crop yield. Banana cultivars with Musa balbisiana genes tend to be more drought tolerant than cultivars of
Musa acuminata. Symptoms of drought stress include folding of the leaves, pale green to yellow leaf color development, and premature leaf death. Severe drought stress may cause choking and pseudostem collapse.

Banana plants are not flood tolerant. In general, plants may survive 24 to 48 hours of flooding caused by moving water. Stagnant water kills plants quickly. Bananas should not be planted in flood-prone areas. In areas where the water table is high and/or where frequent soil saturation or very brief flooding occurs, planting on beds is recommended. Symptoms of continuously wet but not flooded soil conditions include plant stunting, leaf yellowing, and reduced yields.

Shade: Banana plants are reported to be moderately shade tolerant (up to 50\%). However, shading delays plant and fruit growth and development. In more subtropical areas like Florida, full or near-full sun is recommended for best production. Excessively shaded plants are stunted and produce small, poor quality fruit.

Salinity: Banana plants do not grow or fruit well in saline soils. Symptoms of salt damage include yellowing and death of the leaf margins, and thin, deformed fruit.

Altitude: Depending upon the local climate, bananas may be grown from sea level to $6,562 \mathrm{ft}$ $(2,000 \mathrm{~m})$.

\section{Soils}

Bananas do best on flat (slope 0-1\%), well drained, deep soils high in organic matter with a $\mathrm{pH}$ of 5.5-7.0. However, many cultivars perform satisfactorily on the sandy, loamy, muck, and calcareous marl and rocky soils found in south Florida. The most important factor is soil drainage. In those areas susceptible to wet or flooded soil conditions, sufficiently high beds or mounds should be constructed and proper engineering (sloping) of the land for water drainage should be done. The beds will place most of the root system above the saturated soil layer and proper sloping of the ditches between beds should allow for drainage of excessive water off the land. 


\section{Propagation}

The most common propagation material is suckers, or pieces of the rhizome. There are 3 types of suckers: maidenhead, a large non-fruiting pseudostem (plus roots and some rhizome); sword sucker, a sucker attached to the original (mother) rhizome with narrow sword-like leaves, and; a water sucker, a sucker next to but only superficially attached to the mother rhizome with broad leaves. Water suckers produce inferior fruit and are therefore not recommended. Large sword suckers and maidenheads are the preferred planting material. Sword suckers should be removed from vigorous clumps with a spade when they are 4-5 ft (1.2-1.5m) tall. The largest leaves are cut off, leaving only the youngest or none at all. Suckers should have many healthy roots, without symptoms, such as nodulations and internal lesions, of nematode or borer damage. The pseudostems of maidenhead suckers are cut down to 8 inches $(20 \mathrm{~cm})$ high and the remaining rhizome is cut into "seed" pieces for planting. In the event that healthy propagating material is not available, the sucker is cut off and its rhizome is pared of all damaged roots and dark tissue, or is cut into pieces containing only white, healthy tissue and a few buds. If nematodes are a problem in the area, it is strongly recommended that nematode-free or hotwater-treated (described under nematodes) propagating material be used.

Bananas have recently begun to be commercially propagated from meristems by tissue culture. The advantage of this system is that plants are uniform and free of nematodes and most diseases. The disadvantage is the time it takes for small plants to be grown to a sufficient size for sale from the nursery and in some areas their lack of availability.

In south Florida, March, April and May are the best months for planting if irrigation is available. Otherwise planting should be delayed until the onset of the rains in June. Planting holes should be large (3 $\mathrm{ft}$ wide by $2 \mathrm{ft}$ deep; $0.9 \mathrm{~m} \times 0.6 \mathrm{~m}$ ) if possible. Addition and mixing with the native soil of completely composted organic matter or a sand-peat moss mixture may be desirable. Plants should be watered-in thoroughly, and a heavy layer of mulch placed around the suckers immediately after planting will assist in keeping the soil moist and will suppress weeds.

\section{Varieties}

There are many banana cultivars. Parents of the cultivated types are Musa acuminata and Musa balbisiana, two wild species which are usually seedy. Banana cultivars are complex diploid, triploid, and tetraploid hybrids among $M$. acuminata and $M$. balbisiana. In general, those with a high proportion of $M$. acuminata produce sweet fruit, whereas those with a high proportion of $M$. balbisiana produce starchy fruit.

Conventionally, the relative contribution of $M$. acuminata and M. balbisiana to the cultivar is indicated with As and Bs, respectively. They are further classified as to the presence of one or more sets of chromosomes (called ploidy level). For example, an $\mathrm{AB}$ is diploid, an $\mathrm{AAB}$, triploid, and $\mathrm{ABBB}$, tetraploid. Triploid cultivars are the most common, diploids somewhat less common, and tetraploids, uncommon.

There are numerous banana and plantain cultivars listed in Table 1 and Table 2. However, many of them are not adapted to Florida's climate and are not readily available. Cultivars have many local names, making identification of specific clones by common name difficult. To help avoid this, common names along with their $\mathrm{A} / \mathrm{B}$ constitution and ploidy level are used.

\section{Comments on Selected Banana Cultivars in Florida}

There are two major diseases that limit production of some banana cultivars. Sigatoka disease is composed of two closely related fungal organisms (commonly called Yellow Sigotoka and Black Sigotoka) which attack and kill banana leaves. This may weaken the plant dramatically and reduce or eliminate fruit production. Black Sigatoka is more of a problem in large commercial plantings than for isolated clumps of bananas in the home landscape. Black Sigatoka may or may not be a major problem for most banana varieties in the home landscape in Florida. Black and Yellow Sigatoka are more of a problem during continuously raining conditions. 
Panama disease is a fungal disease that attacks the banana roots and colonizes the conducting tissue of the pseudostem, causing the plant to collapse. In the home landscape situation, soil infested with Panama disease will limit the varieties that may be successfully grown.

'Gros Michel' (AAA) does not produce well in Florida. It has poor cold tolerance and is susceptible to Panama disease and Sigatoka. It is not recommended for planting in the home landscape.

In general, the Cavendish group (AAA) is resistant to Panama disease, but is susceptible to Sigatoka disease. The characteristic that distinguishes the best known clones is the height of the pseudostem. The tallest clone is 'Lacatan' followed by 'Robusta' and 'Giant Cavendish,' 'Grand Nain,' and 'Dwarf Cavendish.' 'Valery,' a common type in Central America, is considered the same as 'Robusta' by some taxonomists. 'Dwarf Cavendish' produces large bunches of medium-sized fruit. It is widely planted and better adapted to the cool climate of the subtropics than most other commercial cultivars. 'Dwarf Cavendish' is recommended for south Florida where, in frost-free years and with good care, it produces abundant fruit. One disadvantage to the 'Dwarf Cavendish' is its susceptibility to Black Sigatoka disease. Another with reported tolerance to cool subtropical areas is 'Williams' (also called 'Williams Hybrid').

There are many cultivars named 'Ladys Finger.' The most common 'Ladys Finger' in south Florida is an AAB, also called 'Pome,' 'Brazilian,' and 'Prata'. It is a tall-growing clone tolerant to cool conditions with small, sweet fruit. However, because of its susceptibility to wind damage and Panama disease, it should only be planted in wind protected areas and land not previously infested with this disease.

There are numerous common cultivars named 'Apple'. The most common 'Apple' in south Florida is an AAB. It is also called 'Silk,' 'Manzana,' and 'Manzano'. It is a dessert-type banana with a pleasant, sub-acid flavor when fully ripe and is common in the Caribbean. The plant is medium-sized and susceptible to Sigatoka and Panama disease. It is only recommended for home landscape planting in Panama-disease-free sites with disease-free planting material.

'Hua moa' (AAB) also called 'Hawaiano' is a leading cultivar in south Florida despite its susceptibility to Panama disease and its poor cold tolerance. The fruit can be eaten fresh or cooked and makes excellent fried green and smashed bananas. 'Hua moa' requires intensive care and is recommended only for planting with disease-free material in warm, protected sites free of Panama disease.

There are several relatively new banana cultivars that produce excellent quality fruit and have resistance to one or more major banana diseases (i.e., Panama and Sigatoka diseases). 'FHIA-01' (also called 'Goldfinger') is an excellent dessert banana with resistance to Panama disease and Yellow and Black Sigatoka. 'FHIA-02' (also called 'Mona Lisa') is resistant to Sigatoka but susceptible to Panama disease. 'FHIA-03' is primarily a cooking banana but may be eaten fresh and is resistant to Panama, Moko, and Sigatoka diseases. 'FHIA-17' is a dessert banana with resistance to Panama disease and tolerance to Sigatoka. 'FHIA-21' is resistant to Back Sigotoka disease. These banana varieties are highly recommended for the home landscape.

\section{Planting a Banana Plant}

\section{Site Selection and Spacing}

In general, banana plants should be planted in full sun for best growth and fruit production. However, banana plants do tolerate light shade. In general, select a part of the landscape away from other trees, buildings and structures, and power lines. Banana plants may be planted $10 \mathrm{ft}$ or more adjacent to outdoor walls as a sunscreen. Caution, placing banana plants near windows may be hazardous because of potential toppling during strong winds. Select the warmest area of the landscape that does not flood (or remain wet) after typical summer rainfall events.

Planting distance for banana plants varies with the ultimate size of the variety. Dwarf or small stature banana plants may be planted $20 \mathrm{ft}$ or more from other plants but may be planted as close as $8 \mathrm{ft}$ 
from other dwarf or small stature banana plants. Large banana varieties should be planted 12 or more feet from other banana plants to leave room for expansion of the mat.

With judicious watering, fertilization, timely weeding, pseudostem pruning, and the use of large healthy suckers for planting material, fruits will mature in 10 - 24 months after planting. The time from planting rhizomes to first harvest usually takes longer to produce fruit and the first bunch is, as a rule, smaller than normal.

\section{Planting in Sandy Soil}

Many areas in Florida have sandy soil. Remove a 3- to $10-\mathrm{ft}$ (0.9- to 3.1-m) diameter ring of grass sod. Dig a hole 3 to 4 times the diameter and 3 times as deep as the container the banana plant has come in. Making a large hole loosens the soil adjacent to the new tree, which makes it easy for the roots to expand into the adjacent soil. It is not necessary to apply fertilizer, topsoil, or compost to the hole. In fact, placing topsoil or compost in the hole first and then planting on top of it is not desirable. If you wish to add topsoil or compost to the native soil, mix it with the soil excavated from making the hole in no more than a 50-50 ratio.

Backfill the hole with some of the native soil removed to make the hole. Remove the plant from the container and place it in the hole so that the top of the soil media in the container is level with or slightly above the surrounding soil level. Fill soil in around the plant roots and tamp slightly to remove air pockets. Immediately water the soil around the plant and plant roots. Staking the plant with a wooden or bamboo stake is optional. However, do not use wire or nylon rope to tie the tree to the stake because they may eventually damage the tree trunk as it grows. Use a cotton or natural fiber string that will degrade slowly

\section{Planting in Rockland Soil}

Many areas in Miami-Dade County have a very shallow soil and several inches below the soil surface is a hard calcareous bedrock . Remove a 3- to $10-\mathrm{ft}$ (0.9- to 3.1-m) diameter ring of grass sod. Make a hole 3 to 4 times the diameter and 3 times a deep as the container the banana plant has come in. To dig a hole there are several options: use a pick and digging bar to break up the rock or contract with a company that has augering equipment or a backhoe. Plant as directed in the section above.

\section{Planting on a mound}

Many areas in Florida are within $7 \mathrm{ft}(2.1 \mathrm{~m})$ or so of the water table and experience occasional flooding after heavy rainfall events. To improve plant survival, consider planting fruit trees on a $2-$ to $3-\mathrm{ft}$ (0.6-0.9 $\mathrm{m}$ ) high by 4 - to $10-\mathrm{ft}$ (1.2- to $3.1-\mathrm{m})$ diameter mound of native soil.

After the mound is made, dig a hole 3 to 4 times the diameter and 3 times as deep as the container the banana plant has come in. In areas where the bedrock nearly comes to the surface (rockland soil), follow the recommendations for the previous section. In areas with sandy soil, follow the recommendations from the section on planting in sandy soil.

\section{Care of a Banana Plant (Mat) in the Home Landscape}

A calendar outlining the month-to-month cultural practices for banana is shown in Table 3.

\section{Fertilizer}

Banana plants need fertile conditions and an abundance of soil moisture for best growth and production. The type of development the plant makes in the first 3 to 4 months determines the weight of the bunch and the number of hands. Consequently, it is essential to provide the best of care during this period.

In soils with low fertility, such as the sandy and calcareous soils of south Florida, bananas should be fertilized frequently (4 to 6 times) for maximum production. The potash requirement is high and fertilizers with a high $\mathrm{K}_{2} \mathrm{O}$ content should be used, e.g., $\mathrm{N}-\mathrm{P}_{2} \mathrm{O}_{5}-\mathrm{K}_{2} \mathrm{O}$ in a ratio of 3-1-6. The amount of fertilizer depends on the size and age of the stalk and on the number of stalks per clump (Table 4).

Young plants should be started with $1 / 2 \mathrm{lb}(0.23$ $\mathrm{kg}$ ) of a 6-2-12 or similar formula (3-1-6 ratio) with 2-3\% magnesium applied every 2 months, and 
increasing gradually to $5.0 \mathrm{lb}$ to $6.0 \mathrm{lb}(2.3-2.7 \mathrm{~kg})$ at flowering and fruiting time, 10 to 18 months later.

In Florida, at least one nutritional spray containing manganese and zinc is recommended annually. Sources of these elements available at garden centers may be used; follow label directions. Copper should be included in the spray if no copper-containing fungicide is used. Banana plants growing in acid sandy soils may be fertilized with 0.5 to $1.0 \mathrm{lb}$ dry iron sulfate 1 to 2 times during the warmer part of the year. Banana plants growing in high $\mathrm{pH}$, calcareous soils may be fertilized with 1 to 2 oz of chelated iron material (EDDHA) during the warmer part of the year.

\section{Irrigation (watering)}

Bananas require large amounts of water and are very sensitive to drought. Drought results in increased time to flowering and fruiting, reduced fruit size, fruit number, and crop yields. Bananas need about 4 to 6 inches (102-152 mm) of water per month for normal growth and production. Thus about 1 to 1.5 inches $(2.5-4 \mathrm{~cm})$ of water should be applied per week. This is especially important during prolonged dry weather conditions.

Since an adequate soil moisture is essential for good production, particularly during the dry months of the year, provision should be made for irrigation. However, caution should be exercised against over-irrigation. Bananas are extremely susceptible to damage by flooding, continuously wet soils, and soil with inadequate drainage.

\section{Weed control}

Weeds should be controlled adjacent to banana plants and mats at all times. Weeds compete for water and nutrients with the plant and reduce fruit production. Maintain a weed-free area of 2 to $6 \mathrm{ft}$ around the banana mat with a well draining organic mulch. Apply 2 to 6 inches of mulch from the base of the pseudostems outward. Caution, do not apply systemic herbicides to the trunk area of banana plants as this may cause them to decline or die.

\section{Diseases, Insects, and Nematode Problems}

There are several major diseases, one major insect, and several nematode species that attack bananas in south Florida.

Panama disease (Fusarium wilt) . Panama disease is of worldwide importance and is caused by the soil-borne fungus Fusarium oxysporum f. sp. cubense. There are four known races of the disease, three of which attack one or more banana cultivars. Symptoms of the disease do not appear on young suckers. On mature plants symptoms include progressive yellowing and eventual death from older to younger leaves, so that only the youngest emerging leaf may remain; brown and black discoloration and slimy appearance of the water-conducting vascular system (it may give off a bad odor as well); and death of the plant. At present there is no chemical control available. The only effective control measures are planting in land not infested with the fungus, the use of disease-free propagation material, and the planting of cultivars with resistance to the disease (Table 1 and Table 2). Plantains are resistant to the fungus.

\section{Sigatoka (Yellow Sigatoka and Black}

Sigatoka). Black sigatoka and yellow sigatoka are of worldwide importance; in general, where the two diseases are found, black sigatoka dominates as the most severe disease causing fungus. Black sigatoka is an important leaf disease in Florida. Yellow sigatoka is caused by the fungus Mycosphaerella musicola and black sigatoka y M. fijiensis. Symptoms of yellow sigatoka begin as pale green flecks that become brown with yellow haloes. As the disease progresses, infected areas coalesce, forming large areas of dead leaf tissue. Black sigatoka begins as minute reddish-brown flecks on the lower leaf surface, but as the infection progresses dark flecks may be seen on the upper leaf surface as well. As the disease progresses, the dark areas with yellow haloes surrounding dead leaf tissue coalesce until the entire leaf is killed. Warm temperatures, high humidity, and frequent rainfall are ideal for disease development. Sigatoka does not kill the plant but causes premature defoliation which results in reduced crop yield.

Banana cultivars differ in their susceptibility to sigatoka with the Cavendish group (AAA) and 'Pome' (AAB) bananas being highly susceptible. 
'Sucrier' (AA), 'Bluggoe' (ABB), and 'Silk' (AAB) are of intermediate susceptibility, while 'Mysore' is only slightly susceptible. Fungicides are available for control but may not be necessary for banana plants in the home landscape. For more information, please contact your local Cooperative Extension Agent.

\section{Banana borer or weevil (Cosmopolites}

sordidus). The banana borer lays eggs at the base of the pseudostem and the larvae bore into the pseudostems and rhizome, causing extensive damage. Young plants may be killed by extensive tunneling and mature plants may weaken and topple with a subsequent reduction in yield. Control of the pest includes use of clean (non-infested) planting material and sanitation (removal and/or grinding up old pseudostems). For more information, please contact your local Cooperative Extension Agent.

\section{Sugar cane weevil (Metamasius hemipterus) .}

The sugar cane weevil causes damage and problems similar to those caused by the banana weevil. The larvae tunnel into the pseudostem, building galleries that weaken the plant. For more information, please contact your local Cooperative Extension Agent.

Burrowing nematode (Radopholus similis) and spiral nematode (Helicotylenchus multicinctus).

Feeding of the burrowing nematode causes extensive damage to the root system and rhizome of banana. The spiral nematode causes extensive damage to the fibrous root system. Injured plants are susceptible to invasion by pathogens and toppling. Purchase and use of non-infested plant material (tissue culture plants, suckers or rhizomes) is the best control. If possible inspect the root system and base of the sucker for dead roots prior to purchasing. For more information, please contact your local Cooperative Extension Agent.

\section{Pruning the banana mat}

Pruning the banana mat is necessary for best vegetative growth and fruit production. Allowing numerous pseudostems to grow from a single mat may lead to small bunches of low quality fruit and encourage disease development. In addition, competition among pseudostems prolongs the time to flowering and to harvest.
A banana pseudostem (stalk) produces fruit only once. After harvest, the stalk is cut off at the base and chopped into small pieces which are left on the ground and incorporated in as mulch. New pseudostems (follow-up stalks, sword suckers) which have been allowed to grow from the rhizome (also called a mat) will produce the next crop. For best production, there must be ample space between plants to avoid crowding and competition for water, light and nutrients.

The number of pseudostems and their replacement is controlled by cutting off new suckers as soon as they appear. A good practice consists of having only one pseudostem flowering and fruiting, one pseudostem about half grown, and one small sucker or peeper per mat. Cutting unwanted suckers or peepers off at ground level and then gouging out as much as possible of what remains with a metal digging bar or piece of rebar will kill the underground bud. It is important that the internal bud is killed, otherwise regrowth occurs very quickly and it takes an unnecessary amount of labor to keep suckers from growing.

Though labor intensive, the cutting of dead leaves and of leaves that rub against the bunch is recommended. Removing the end of the flowering stalk which has no fruit and hangs below the last hand of bananas will speed fruit development if it is done immediately after the female flowers have set fruit.

\section{Banana plants and lawn care}

Banana plants in the home landscape are susceptible to pseudostem injury caused by lawn mowers and weed eaters. Maintain a grass-free area 2 to $5 \mathrm{ft}$ or more away from the pseudostem. Never hit the pseudostem with lawn mowing equipment and never use a weed eater near the pseudostem. Mechanical damage to the pseudostem of the plant will result in weakening the pseudostem and if severe enough can cause the psuedostem to decline or die.

Roots of mature banana plants (mats) spread 6 to $10 \mathrm{ft}$ beyond the mat and use of some feed and weed materials of the lawn adjacent to a mat is not recommended and may reduce fruiting and or fruit quality. The use of lawn sprinkler systems on a timer may result in over watering and cause banana plants 
to decline. Too much water applied too often results in root rot.

\section{Mulch}

Mulching banana mats in the home landscape helps retain soil moisture, reduces weed problems adjacent to the tree trunk, and improves the soil near the surface. Mulch with a 2- to 6-inch (5- to 15-cm) layer of bark, wood chips, or similar mulch material.

\section{Harvesting}

Bunches are generally harvested when the fingers are plump but before they begin to turn yellow. However, bananas may be picked at different times for different purposes. In general, bananas for fresh consumption in the home landscape may be picked when they have reached or nearly reached the normal size for a particular variety. Usually, this is when the edges of the fruit have smoothed out and the sides of the fruit have swelled. Homeowners may want to harvest fruit 7 to 14 days prior to ripening on the plant. Hanging the fruit in a shady, cool place to ripen seems to allow development of better flavor than if allowed to ripen on the plant. Bananas may also be cooked and consumed when still green or when very ripe as is done with plantains. The FHIA banana varietes 01, 02, 03 and 21 may be eaten fresh when ripe or cooked when green. Bananas are a good source of nutrients, especially potassium (Table 5).

Bananas should not be refrigerated prior to ripening as this will cause chilling injury. Symptoms of chilling injury include inability to ripen or ripen properly, discoloration of the peel and/or pulp, and poor flavor. Generally, not all the bananas on a stalk ripen simultaneously allowing consumption of the fruit over an extended period of time.

Banana yields vary considerably depending on many factors, but bunches weighing 25 to $40 \mathrm{lbs}$ per pseudostem may be expected. Well-cared-for banana plants may produce bunches up to $100 \mathrm{lbs}$. Factors such as weather, pests and diseases, and cultural practices affect the life of a banana planting. 


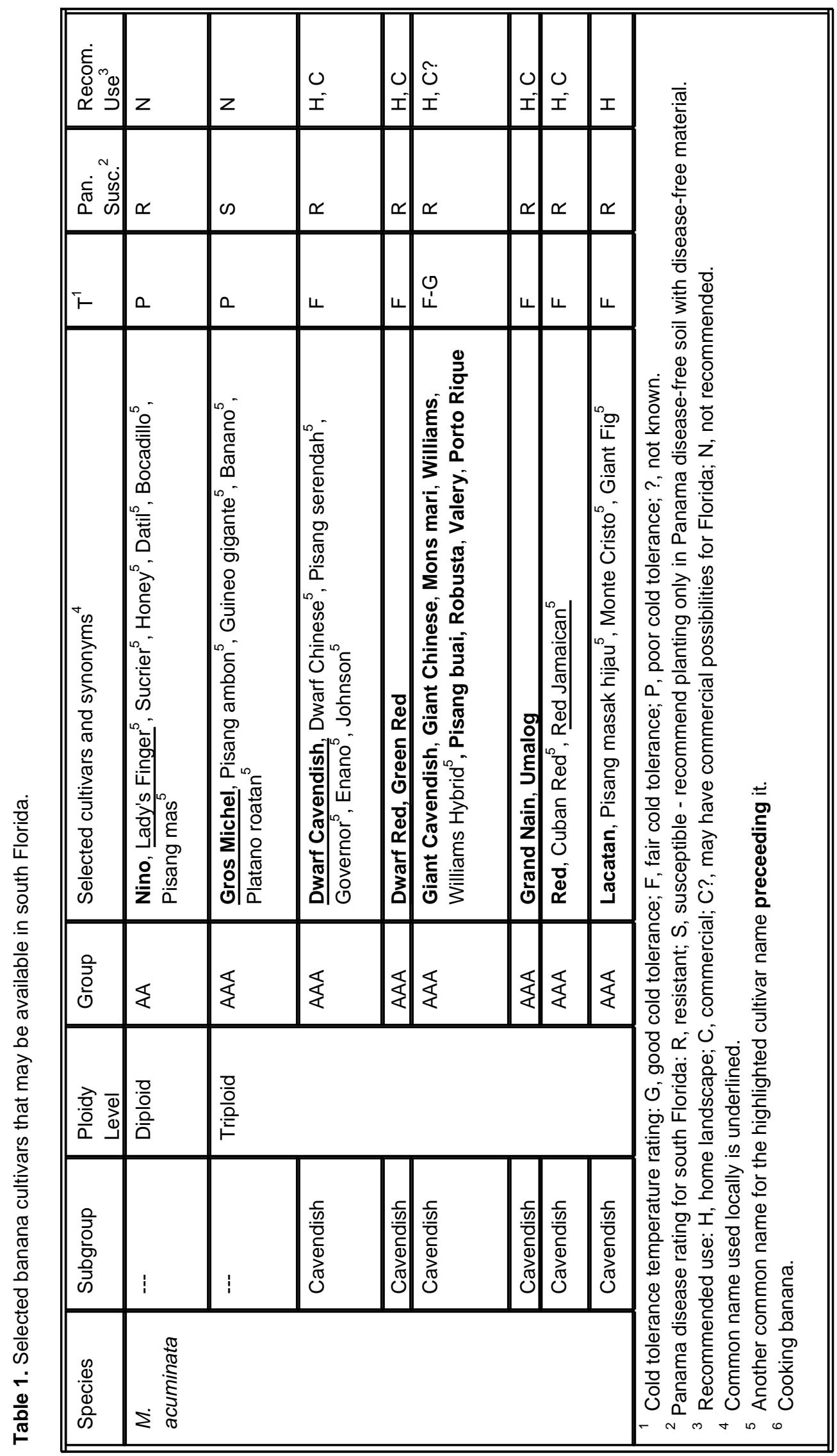




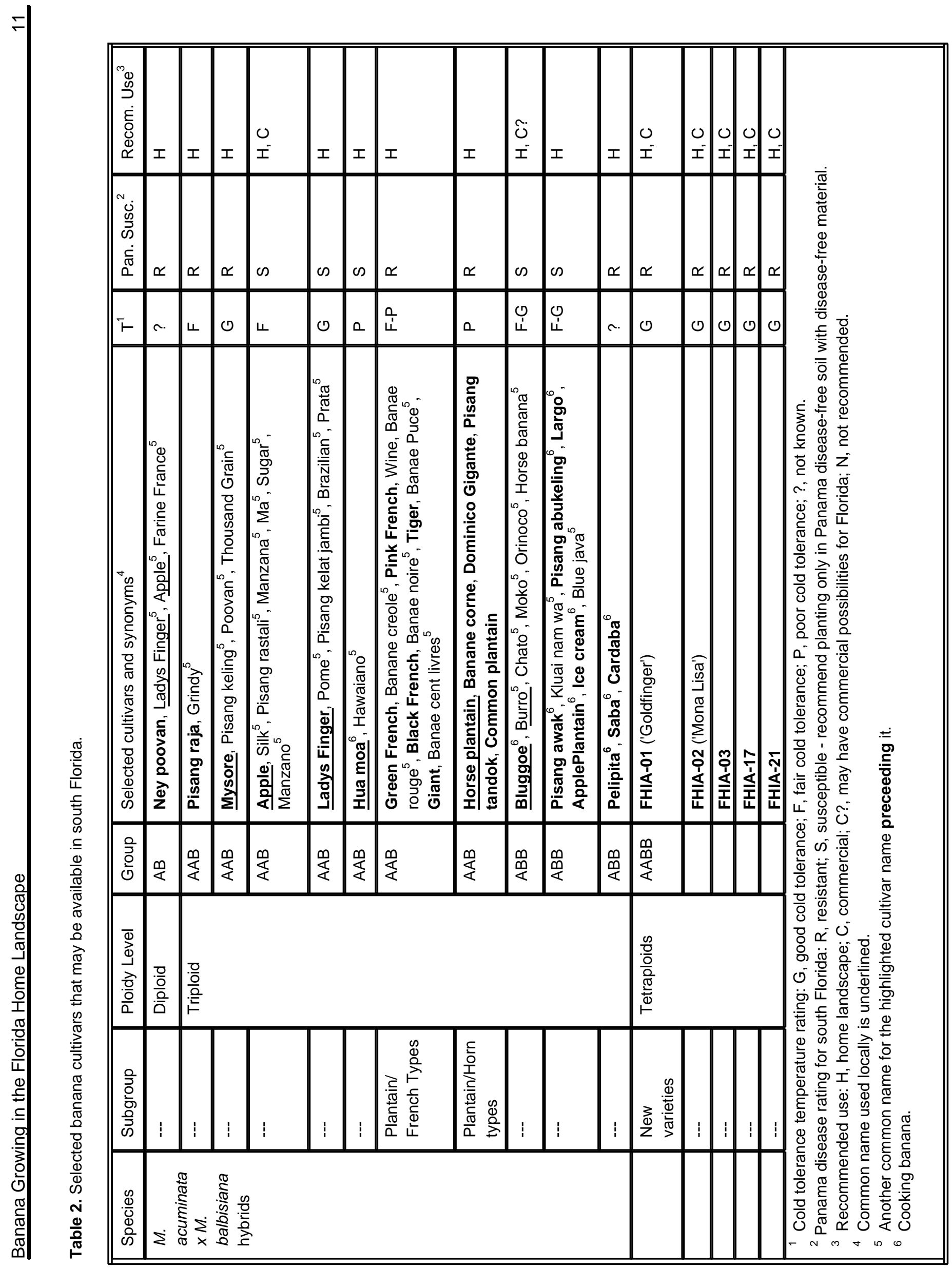


Table 3. Cultural calendar for banana production in the home landscape.

\begin{tabular}{|c|c|c|c|c|c|c|c|c|c|c|c|c|}
\hline Operation & Jan & Feb & March & April & May & June & July & Aug & Sept & Oct & Nov & Dec \\
\hline General $^{1}$ & \multicolumn{12}{|c|}{$\begin{array}{l}\text { Apply nitrogen-phosphate-potash-magnesium-containing fertilizers every } 4 \text { to } 8 \text { weeks throughout the year. } \\
\text { Less may be applied during the winter (i.e., Nov.-Feb.) because of less nutrient demand during cooler weather } \\
\text { conditions. }\end{array}$} \\
\hline $\begin{array}{l}\text { Nutritional } \\
\text { sprays }\end{array}$ & & & & \multicolumn{7}{|c|}{$\begin{array}{l}\text { Apply } 1 \text { or more foliar nutritional sprays containing } \\
\text { magnesium, manganese, and zinc during this time. }\end{array}$} & & \\
\hline $\begin{array}{l}\text { Iron } \\
\text { applications }\end{array}$ & & & & \multicolumn{7}{|c|}{$\begin{array}{l}\text { Soil applied iron may be applied during the warm season } 1 \text { to } 2 \\
\text { times. }\end{array}$} & & \\
\hline Watering & \multicolumn{12}{|c|}{ Banana plants should be watered regularly during any dry period without substantial rainfall. } \\
\hline $\begin{array}{l}\text { Insect } \\
\text { control }^{2}\end{array}$ & \multicolumn{12}{|c|}{$\begin{array}{l}\text { Monitor the base of banana pseudostems (stalks) for signs of weevil infestation throughout the year. Use } \\
\text { insect-free planting material to establish any new plants or plantings. }\end{array}$} \\
\hline $\begin{array}{l}\text { Disease } \\
\text { control }^{2}\end{array}$ & \multicolumn{12}{|c|}{$\begin{array}{l}\text { Monitor banana leaves for sigatoka infestation. Periodic applications of copper and/or horticultural oil may be } \\
\text { beneficial during prolonged wet periods (i.e., during summer) although this may not be necessary for banana } \\
\text { plants in the home landscape. }\end{array}$} \\
\hline Pruning & \multicolumn{12}{|c|}{$\begin{array}{l}\text { Maintain } 3 \text { to } 4 \text { pseudostems (stalks) of different ages: } 1 \text { stem that is flowering and/or fruiting; } 1 \text { that is } 1 / 2 \text { to } \\
2 / 3 \text { the size of the stalk with flowers and fruit; } 1 \text { to } 2 \text { sword suckers (small } 6 \text { inches to } 3 \mathrm{ft} \text { tall) throughout the } \\
\text { year. }\end{array}$} \\
\hline \multicolumn{13}{|c|}{$\begin{array}{l}1 \text {, The potash requirement for banana is high and fertilizers with a high potash }\left(\mathrm{K}_{2} 0\right) \text { content should be used, e.g., } \mathrm{N}-\mathrm{P}_{2} \mathrm{O}_{5} \\
-\mathrm{K}_{2} \mathrm{O} \text { in a ratio of } 3-1-6 \text {. } \\
2 \text {, Monitor plants for signs of insect and disease infestation throughout the year. Contact your local County Cooperative } \\
\text { Extension Agent for current control recommendations. }\end{array}$} \\
\hline
\end{tabular}

Table 4. Fertilizer program for banana plants in the home landscape

\begin{tabular}{|c|c|c|c|c|}
\hline $\begin{array}{l}\text { Months from } \\
\text { planting a } \\
\text { sucker or } \\
\text { piece of } \\
\text { rhizome }\end{array}$ & $\begin{array}{l}\text { Times per } 6 \\
\text { months }\end{array}$ & $\begin{array}{l}\text { Amount/mat/ } \\
\text { application } \\
\text { (lbs) }\end{array}$ & $\begin{array}{l}\text { Nutritional } \\
\text { sprays } \\
\text { (times/year) }^{2}\end{array}$ & $\begin{array}{l}\text { Iron } \\
\text { applications } \\
\text { (times per } \\
\text { year) }\end{array}$ \\
\hline $1-6$ & 3 & $0.50-1.0$ & $1-2$ & $1-2$ \\
\hline $6-12$ & 3 & $1.0-3.0$ & $1-2$ & $1-2$ \\
\hline $12-18$ & 3 & $3.0-5.0$ & $1-2$ & $1-2$ \\
\hline $18+$ & 3 & $5.0-6.0$ & $1-2$ & $1-2$ \\
\hline \multicolumn{5}{|c|}{$\begin{array}{l}\text { 1, Dry fertilizer containing nitrogen, phosphate, potash, and magnesium should } \\
\text { be applied every } 2 \text { months throughout the year. } \\
2 \text {, Foliar applications of micronutrients may be made } 1 \text { to } 2 \text { times per year; } \\
\text { follow label instructions. } \\
3 \text {, Iron applications should be made to the soil } 1 \text { to } 2 \text { times per year. }\end{array}$} \\
\hline
\end{tabular}


Table 5. Nutrient value of raw banana fruit (3.5 oz or $100 \mathrm{~g}){ }^{1}$

\begin{tabular}{||l|l|l|l|l|l||}
\hline \hline Constituent & $\begin{array}{l}\text { Approximate } \\
\text { value }\end{array}$ & Constituent & $\begin{array}{l}\text { Approximate } \\
\text { value }\end{array}$ & Constituent & $\begin{array}{l}\text { Approximate } \\
\text { value }\end{array}$ \\
\hline $\begin{array}{l}\text { Water } \\
\text { content }\end{array}$ & $75 \%$ & Carbohydrate & $22.8 \mathrm{~g}$ & Phosphorus & $22 \mathrm{mg}$ \\
\hline Calories & $89 \mathrm{kcal}$ & $\begin{array}{l}\text { Total dietary } \\
\text { fiber }\end{array}$ & $2.6 \mathrm{~g}$ & Potassium & $358 \mathrm{mg}$ \\
\hline Protein & $1.1 \mathrm{~g}$ & Calcium & $5 \mathrm{mg}$ & Sodium & $1 \mathrm{mg}$ \\
\hline Fat & $0.33 \mathrm{~g}$ & Iron & $0.26 \mathrm{mg}$ & Vit. C & $8.7 \mathrm{mg}$ \\
\hline Cholesterol & $0.0 \mathrm{~g}$ & Magnesium & $27 \mathrm{mg}$ & Vit. A & $64 \mathrm{IU}$ \\
\hline $\begin{array}{l}\text { 1, Data from USDA National Nutrient Database for Standard Reference at } \\
\text { http://www.nal.usda.gov/fnic/foodcomp/search/. }\end{array}$ & \\
\hline \hline
\end{tabular}

